\title{
Variability of the Polish species of the genus Riccardia (Hepaticae, Aneuraceae). I. Herbarium material
}

\author{
M. MENDELAK
}

\author{
Department of Genetics, Adam Mickiewicz University \\ (Received: December 27, 1972)
}

\begin{abstract}
Population samples of three species: Riccardia palmata, $R$. latifrons and $R$. chamedryfolia* from 184 stations were biometrically examined. The high intraspecific variability and the existence of intermediate forms were confirmed.
\end{abstract}

\section{INTRODUCTION}

The genus Riccardia Gray (Aneura Dum. pp) comprising about 150 species is represented in Poland as in the whole of Europe by five taxa: $R$. incurvata Lindb., R. multifida (L.) Gray, R. latifrons Lindb., R. palmata (Hedw.) Carr. and R. chamedryfolia (With.) Grolle. Riccardia pinguis Gray belongs to a separate genus (Schuster 1958; Grolle 1960).

The classification of this genus is still very complicated, even as regards the European taxa. In the available publications discrepancies and unclear statements are found in the descriptions of the particular species as regards cell size, width and shape of the thallus ( $\mathrm{S}$ c h u s ter 1953; Müller 1954; Rejment-Grochowska 1966; Arnell 1956), the occurence of oil bodies (Müller 1954; Rejment-Grochowska 1966; Little 1968) and thickening of sporangium walls (M üller 1954; Evans 1937; Savich-Ladyzhenskaya 1956; Mizutani-Hattori 1957; Z erov 1939; Macvicar 1960).

The taxonomy of three species: $R$. latifrons, $R$. palmata and $R$. chamedryfolia is particularly difficult. It seemed useful, therefore, to examine closer the character of the variability of these three taxa by new experimental-numerical methods.

In the present paper the results of investigations on herbarium material are reported.

* According to R. Grolle (1969) the name of R. sinuata should be $R$. chamedryfolia (With.) Grolle. 


\section{MATERIAL AND METHODS}

Population samples from 184 stations were examined (M e n d e lakin press), belonging to the species $R$. latifrons, $R$. palmata and $R$. chamedryfolia. In view of the relatively simple thallus structure in the above mentioned species, the measurements concerned mainly the cell size and
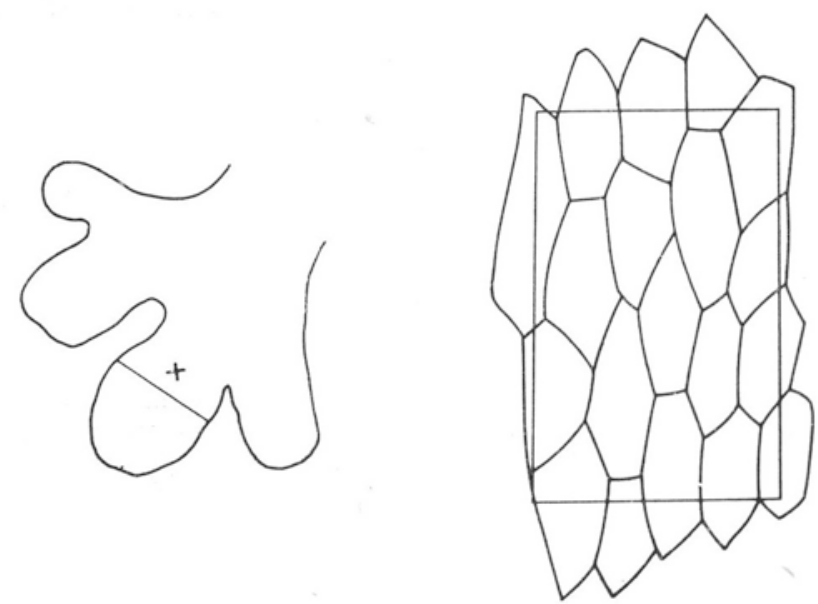

Fig. 1. Drawing illustrating the technique of measurement of the thallus width and mean surface area of epidermai cells

width of the thallus. For making possible observation of the inner cell layers, the thallus was boiled for $2 \mathrm{~min}$ in 80 per cent lactic acid. Then at a definite site - somewhat above the base of the branching of the last order - the length and width of the epidermal and subepidermal cells were measured. The mean surface area of the epidermal cells was calculated from drawings executed with Abbe's apparatus with the use of an ocular scale demarcating a constant surface (about $0.25 \mathrm{~mm}^{2}$ ). The thallus width (its widest arm) was also calculated from drawings. The site and way of taking measurements are shown in Fig. 1.

From each sample three thalli were taken (in doubtful cases 10 thalli) and investigated in respect to four chosen characters:

1. length of average epidermal cell,

2. length of longest subepidermal cell,

3. average surface area of epidermal cell,

4. thallus width.

The measurement data were used for preparing a scatter diagram (Anderson 1949) and dendrite (Florek, Eukaszewicz and other 1951, Kowal, Kuźniewski 1958, Kowal 1965). From among the possible procedures, in the present study the one based on the shortest 
euclidean distance was applied as most suitable for this kind of investigations ( $\mathrm{Szw}$ eykowski, Krzakowa 1967).

In the further text all the samples will be denoted with letters added to the succesive numbers: 1 . to $R$. latifrons samples, p. to $R$. palmata, ch. to $R$. chamedryfolia to facilitate the readings.

\section{RESULTS}

On the basis of the measurements diagrams were constructed (Figs 2 and 3) showing the wide dispersion of the individual points of the three species investigated. The points of Riccardia chamedryfolia lie completely within the area of $R$. latifrons, forming with this species one group. Thus, in the case of these two species the characters taken into account cannot be considered as distinguishing ones. This group of points common to both species is not strictly delimited, too, from the second grouping of the individual points of $R$. palmata. The dispersion is so wide that, even in the case of diagram 2 , mixture of some points belonging to both species may be observed.

The occurence of certain number of points on the border between two groups may be seen on both diagrams, although this does not always concern the same samples. We find there populations which in both combinations of characters preserve their intermediate character (e.g. 9 1., 21 l., 43 1., 56 1., 69 l., 70 p., 72 p., 73 p., 74 p., 95 p.) and such populations, the points of which lie in one combination in the middle or at the limits of their groups and in the other combination distinctly within them (e.g. 1 1., 2 1., 4 1., 6 1., 10 1., 32 1., 7 p.). Finally there also are such populations (e.g. 11 p. and 69 p.) in which three characters are of intermediate character, while the fourth is typical for one of the species.

Thus, it appears that the characters investigated are not correlated. Therefore, a dendrite was prepared in order to find out what will be the picture of variability if all the four characters are jointly taken into account. For technical reasons only samples of 100 populations were included. These were chosen from the entire material from various regions of the country which later were to serve for detailed investigations. All those which on the scatter diagrams occupied intermediate places were included too.

This dendrite (Fig. 4) indicates even more clearly than the preceding diagrams the morphological continuity between the taxa investigated. Similarly as in the other diagrams the points representing the $R$. chamedryfolia samples lie among those for $R$. latifrons, and the delimitation between the remaining two groups is not clear either. What is more, the 
distances between $R$. latifrons and $R$. palmata (i.e. between samples $71 \mathrm{l}$. and $95 \mathrm{p}$. and $43 \mathrm{l}$. and $72 \mathrm{p}$.) are shorter than those between some samples within the first species (e.g. $33 \mathrm{l}$. and $35 \mathrm{l}$; $68 \mathrm{l}$. and $74 \mathrm{l}$; 64 p. and 69 p.; 67 p. and 89 p. etc.).

The samples which previously showed the intermediate character on the scatter diagrams, e.g. 70 p., 72 p., 95 p., 9 l., 21 l., 56 l., 71 1., 72 1. preserved their intermediate position in the dendrite too. The sample $43 \mathrm{l}$., however, passed into the region of $R$. palmata.

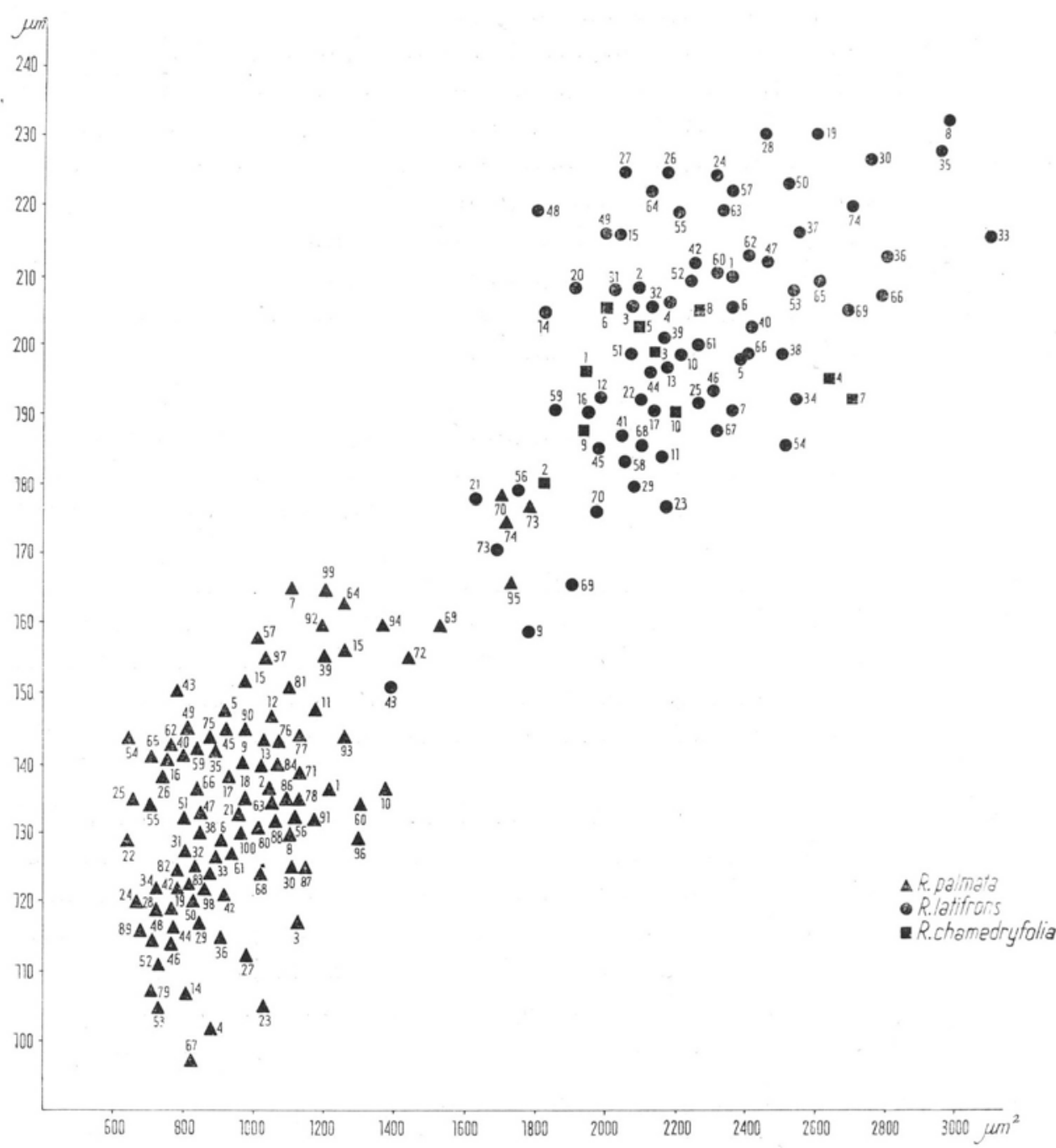

Fig. 2. Scatter diagram constructed on the basis of mean values of the characters for herbarium material. Each point denotes a mean from 3 (or 10) thalli from the given sample 

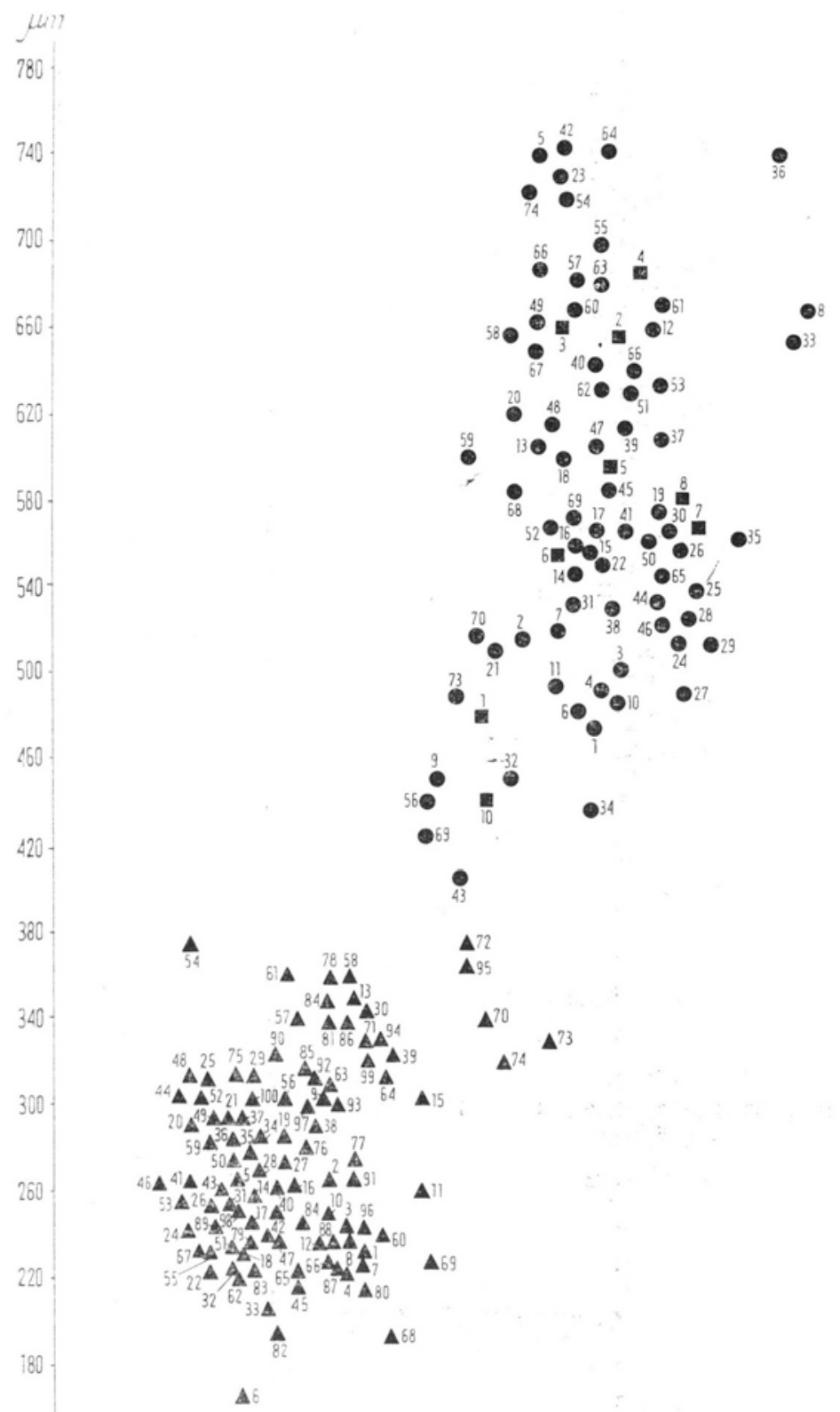

$\Delta$ R.palmata

- R.latifrons

a.chamedryfolia

$\mathbf{A} 6$

$30 \quad 40 \quad 50 \quad 60 \quad 70 \quad 80 \quad 90 \quad 100 \quad 110 \quad 120 \quad r$

Fig. 3. Scatter diagram constructed on the basis of mean values of the characters for herbarium material. Each point denotes a mean from 3 (or 10) thalli from the given sample 


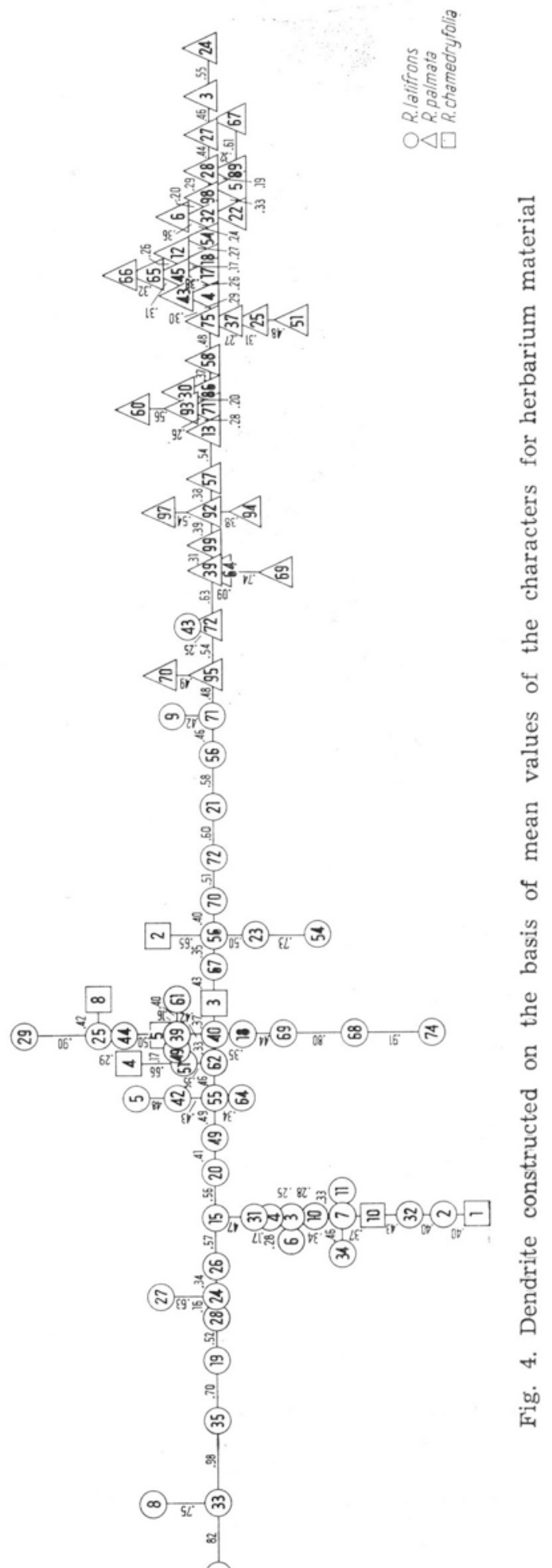

(:) 


\section{CONCLUSIONS}

Biometric examination of characters utilized for determination of herbarium material of three species of the Riccardia genus, namely, the length of the epidermal and subepidermal cells, the average surface area of the epidermal cell and the thallus width, demonstrated that:

1. none of these characters taken alone allows sharp delimitation of the species investigated, since there always exist intermediate forms,

2. it is not possible to delimit sharply these species either when pairs of characters (scatter diagram) or when all the four characters together (dendrite) are used for this purpose,

3 . the character of the intermediate forms, as well as the character of the limit between the species requires a more precise elaboration by experimental-numerical methods; the results of these investigations will be reported in part II (in press).

I am very indebted to Prof. Dr. Jerzy Szweykowski for his interest and helpful advice.

The work was supported partially by a grant from the Botanical Committee of the Polish Academy of Sciences.

\section{REFERENCES}

Anders on E., 1949. Introgressive Hybridization.

Arnel1 S., 1956. Illustrated Moos Flora of Fennoscandia, Lund.

Evans A. W., 1937. The structure of the capsule wall in certain species of Riccardia, Annales Bryologici 10: 20-35.

Florek K., Łukaszewicz J., Perkal J., Steinhaus H., Zubrzycki S.,

1951. Taksonomia Wrocławska, Przegląd Antropol. 17: 193-211.

Grolle R., 1960. Zur Nomenklatur von Riccardia pinguis, Trans. Brit. Bryol. Soc. 3(5): $746-747$.

Grolle R., 1969. Miscellanea hepaticologica 100, Trans. Brit. Bryol. Soc. 5(4): $772-773$.

Kow a 1 T. 1965. Zasady i przykłady systematyki roślin metodą dendrytową, Prace

Wrock. Tow. Nauk., Ser. B, 117.

Kowal T., Kuźniewski E. 1958. Metoda dendrytowa i sposób jej zastosowania, Wiad. Bot. 2(3): 141-147.

Little E. R. 1968. The oil bodies of the genus Riccardia Gray, Trans. Brit. Bryol. Soc. 5(3): $536-540$.

Macvicar S. 1960. The Students Handbook of British Hepatics.

Mizutani M., Hattori S. 1957. An etude on the systematics of japanese Riccardias, Jour. Hatt. Bot. Lab., 18: 27-64.

M üller K., 1954, Die Lebermoose Europas I.

Rejment-Grochowska I., 1966. Wątrobowce I.

S a wicz Ł. I., Ła dyżenskaja K. I. 1936. Opredielitiel pieczenocznych mchow sjewiera ewropejskoj czastii SSSR.

Schuster R. M. 1953. Boreal Hepaticae, The Am. Midl. Natur. 42(3): 513-712. 
Schuster R. M. 1958. Annotated key to the orders, families and genera of Hepaticae, The Bryologist 61(1): 1-66.

Szweykowski J., Krzakow a M. 1967. Variation in Pleuroclada albescens, II.

The dendrite method, Bull. Soc. Am. Sci. et Lettr., Ser. D, 8: 97-102.

Z e r ow K., 1939. Wyznacznik pieczinocznich mochiw URSR.

$$
\begin{array}{r}
\text { Authors' address: } \\
\text { Dr. Maria Mendelak } \\
\text { Department of Genetics, } \\
\text { Adam Mickiewicz University, } \\
\text { Dqbrowskiego 165 } \\
\text { 60-594 Poznañ, Poland }
\end{array}
$$

\section{Zmienność polskich gatunków rodzaju Riccardia (Hepaticae, Aneuraceae)}

\section{Material zielnikowy}

\section{Streszczenie}

Zbadano biometrycznie próby populacji 3 gatunków: Riccardia palmata, $R$. latifrons i $R$. chamedryfolia pochodzące z 184 stanowisk. Zarówno diagramy rozrzutu, jak i dendryt potwierdziły istnienie dużej zmienności wewnątrzgatunkowej. Pomiędzy $R$. palmata i $R$. latifrons stwierdzono ciągłość spowodowaną występowaniem form o charakterze pośrednim pod względem morfologicznych cech ilościowych. 